\title{
Erken Okuryazarlık Gelişimini Belirleme Aracının Geliştirilmesi*
}

Burak Delican ${ }^{1}$

\section{Seyit Ateş²}

\section{Type/Tür:}

Research/Araştırma

Received/Geliş Tarihi: March

16/ 16 Mart 2020

Accepted/Kabul Tarihi:

November 10/ 10 Kasim 2020

Page numbers/Sayfa No: $159-180$

Corresponding

Author/İletişimden Sorumlu

Yazar: burakdelican@gmail.com

\section{$\checkmark$ iThenticate}

This paper was checked for plagiarism using iThenticate during the preview process and before publication. / Bu çalışma ön inceleme sürecinde ve yayımlanmadan önce iThenticate yazılımı ile taranmıştır.

Copyright $(\subset) 2017$ by

Cumhuriyet University, Faculty of Education. All rights reserved.

\section{Öz}

$\mathrm{Bu}$ araştırmanın temel amacı 60 - 84 ay aralığındaki çocukların okuryazarlık gelişimlerini belirlemeye yönelik bir ölçme aracının geliştirilmesidir. $\mathrm{Bu}$ amaçla Erken Okuryazarlık Gelişimini Belirleme Aracı (EGBA) oluşturulmuş ve aracın geçerlik ve güvenirlik çalışmaları yapılmıştır. Araştırma, nicel araştırmanın yapısına uygun olarak ölçek geliştirme mahiyetinde tarama modelinde planlanmıştır ve araştırmanın örnekleminde 60 - 84 ay yaş aralığında olan 781 birinci sınıf öğrencisi yer almaktadır. Erken Okuryazarlık Gelişimini Belirleme Aracının ilk formu ilgili alan yazın, örnek çalışmalar ve uzman görüşleri doğrultusunda oluşturulmuştur. Aracın esas uygulamaya girecek formunun oluşmasında deneme uygulaması sonuçları, ön uygulama sonuçları ve uzman görüşleri belirleyici olmuştur. Esas uygulamada 781 öğrenciden veri toplanmış, toplanan veriler ile geçerlik, güvenirlik ve madde analizi çalışmaları yapılmıştır. İstatistiki analizlerin sonuçları şu şekildedir; Temel Görsel Algı testi 4 boyut altında toplanan 17; Dinleme, İzleme ve Anlama Testi tek faktör atında toplanan 20; Görsel Okuma ve Anlama Testi 3 faktör altında toplanan 15; Sesbilgisel Farkındalık Testi 8 faktör altında toplanan 55; Yazı Farkındalığı Testi 2 faktör altında toplanan 15; Temel Yazma Becerileri Testi 2 faktör altında toplanan 16 madde ile geçerli ve güvenilir ölçümler yapabilmektedir. Ulaşılan sonuçlar Erken Okuryazarlık Gelişimini Belirleme Aracının geçerli ve güvenilir ölçümler yapmada başarılı olduğunu göstermektedir.

Anahtar Kelimeler: Erken okuryazarlık, okuma yazmaya hazırbulunuşluk, okuryazarlık gelişimi, belirleme aracı

\footnotetext{
Suggested APA Citation/Önerilen APA Atıf Biçimi:

Delican, B., \& Ateş, S. (2021). Erken okuryazarlık gelişimini belirleme aracının geliştirilmesi. Cumhuriyet International Journal of Education, 10(1), 159-180. http://dx.doi.org/10.30703/cije.704440
}

\footnotetext{
*Bu çalışma, birinci yazarın ikinci yazar danışmanlığında gerçekleştirdiği “Okuma Yazmaya Hazırbulunuşluğu Belirleme Aracının Geliştirilmesi" isimli doktora tezinden üretilmiştir.
}

1 Dr. Öğr. Üyesi, Tokat Gaziosmanpaşa Üniversitesi, Eğitim Fakültesi, Temel Eğitim Bölümü, Tokat/Türkiye Asst. Prof. Dr., Tokat Gaziosmanpaşa University, Faculty of Education, Tokat/Türkiye e-mail: burakdelican@gmail.com ORCID ID: orcid.org/0000-0003-3187-0001

2 Prof. Dr., Gazi Üniversitesi, Gazi Eğitim Fakültesi, Temel Eğitim Bölümü, Ankara/Türkiye Prof. Dr., Gazi University, Gazi Faculty of Education, Ankara/Türkiye e-mail: seyitates@gmail.com ORCID ID: orcid.org/0000-0002-4498-0376 


\title{
Development of Early Literacy Diagnostic Assessment Tool
}

\begin{abstract}
The main purpose of this study was to develop a measurement tool to evaluate the literacy development of the 60 - 84 months children. For this purpose, Early Literacy Diagnostic Assessment Tool (ELDAT) was developed and the validity and reliability studies of the tool were conducted. The research was planned as a quantitative method survey model involving scale development. In line with the scale development process, subscales were determined based on literature and other studies, and expert opinions were asked. The validity, reliability and item analysis studies were performed on the data obtained from 781 students. The results of statistical analysis were as follows; Basic Visual Perception Test was valid and reliable with 17 items collected under 4 dimensions. Listening, Monitoring and Comprehension Test was valid and reliable with 20 items collected under 1 dimension. Visual Reading and Comprehension Test was valid and reliable with 15 items collected under 3 dimensions. Phonological Awareness Test was valid and reliable with 55 items collected under 8 dimensions. Print Awareness Test was valid and reliable with 15 items collected under 2 dimensions. Basic Writing Skills Test was valid and reliable with 16 items collected under 2 dimensions. The results achieved that the Early Literacy Diagnostic Assessment Tool is successful in distinguishing individuals.
\end{abstract}

Keywords: Early literacy, reading writing readiness, literacy development, assessment tool

\section{Giriş}

Okuma ve yazmanın ne zaman öğretilmesi gerektiği eğitimcilerin önemli çalışma alanlarından biri olmuştur. 1930'lardan 1970'lere kadar eğitimciler okuma ve yazma öğretimi için en iyi zamanın gelmesi gerektiğine inanmışlar ve okuma yazma öğretiminden önce öğrencilerin "hazır olma" durumlarının (biyolojik ve nörolojik olgunlaşma) belirli bir seviyeye getirilmesi gerektiğini savunmuşlardır (Ezell, Justice ve Parsons, 200, s. 131). Bu anlayışa göre çocukların altı buçuk zihin yaşına gelmeden okuma eylemini gerçekleştiremeyecekleri ve yazmanın okumayı öğrendikten sonra öğrenilebileceği düşünülmüştür (Block, 2003, s. 231). 1970'lerden itibaren ise bazı araştırmacılar okuma olgunluğu olarak anılan bu görüşe ve okumaya "hazır olma" kavramlarına karşı çıkarak deneyimler üzerine yoğunlaşmaya başlamışlardır (Durkin, 1968; van Kleeck ve Schuele, 2010). Çocukların okuma yazma süreçlerinin incelenmesi konusunda öncü olan araştırmacılardan Marie Clay “Emergent Literacy” görüşünü ilk ortaya çıkaran araştırmacıdır (Rohde, 2015, s. 1). Türkçede Doğuştancı Görüş (Akyol, 2007) olarak ifade edilebilecek bu görüş, çocukların okuma yazma ile ilgili kavram, tavır ve başarılarını yetişkinlerinkinin benzeri olarak görmekten ziyade bunları çocuğun açısından çözümlemeye çalışmıştır. Bu görüşe göre çocuklar doğumdan itibaren çevrelerinde var olan metinlerle ve işaretlerle etkileşim hâlinde bulunmaktadır. Çocuklar bu etkileşim sürecinde harflerin, iletişim sürecinin bir bileşeni olduğunu ve alfabenin sesleri temsil eden simgesel bir sistem olduğunu anlamaktadir (Riley, 2006).

Okuma yazmayı yeni öğrenen bireyler kelimenin fonolojik yapısını çözümlemede oldukça yoğun çaba gösterirken ilerleyen dönemlerde bu süreç otomatikleşir. Kelimenin fonolojik bileşenleri çözümlenirken bireyin sahip olduğu erken okuryazarlık becerileri (sesbilgisel farkındalık, yazı farkındalığı, dikkat, hafıza $\mathrm{vb}$. faktörler) ise bu yapıya yüklenecek anlamın inşasında belirleyici nitelikte rol 
oynamaktadır. Araştırmacıların bu durumu göz önüne alarak erken okuryazarlık becerilerini geliştirmek/değerlendirmek için pek çok program oluşturduğu ve çeşitli ölçme araçları kullanarak okuma yazma becerilerinin gelişimine yönelik çıarımlar yaptığ görülmektedir (Badian 2001; Bayraktar ve Temel, 2014; Justice ve Ezell, 2000; Whitehurst ve Lonigan, 1998; Sonnenschein ve Munsterman, 2002; Şimşek, 2007). Türkiye' de ise erken okuryazarlık becerilerini değerlendirmeye yönelik oluşturulan veya uyarlanan araçların sayısının sınırlı olduğu göze çarpmaktadır (Karaman, 2013; Kargın, Ergül, Büyüköztürk ve Güldenoğlu, 2015; Oktay, 1983; Polat Unutkan, 2003; Yazıcı, 2010). Bu çalışmalarda araştırmacıların 36 - 72 ay yaş aralığındaki çocukların, sesbilgisel farkındalık, yazı farkındalığı ve sözel dil becerilerinin gelişimi üzerine odaklandıkları görülmektedir.

Türkiye' de ilkokula başlama süreci göz önüne alındığında; öğrencilerin formel okuma yazma becerilerindeki başarısını belirginleştiren erken okuryazarlık becerileri ile ilgili öğrencilerden bilgi toplamak için uygulanan formel bir envanter bulunmamaktadır. Sınıf öğretmenleri öğrencilerin okuryazarlık becerilerini, gözlemleri doğrultusunda, ilk okuma yazma süreci devam ederken fark etmeye çalışmaktadır. Okul öncesi dönem açısından bakıldığında ise öğrencilerin okuryazarlık becerilerini tanılamak için geliştirilen ve uyarlanan çalışmaların olduğu görülmektedir (Karaman, 2013; Polat Unutkan, 2003; Şimşek, 2011; Yazıc1, 2010; Yangın, Erdoğan ve Erdoğan, 2008 gibi). Bu çalışmalar göz önüne alındığında, Türkiye'de çocukların okuryazarlık gelişimlerini belirlemeye yönelik çalışmaların geniş bir alandan daha özel bir alana doğru ilerlediği görülmektedir. Okuryazarlık gelişiminin, ilköğretime hazırbulunuşluk veya okul olgunluğu gibi geniş bir alanı ifade eden kavramlar içinde ele alındığı görülürken; Yangın, Yangın ve Erdoğan, (2008), Yazıcı (2010), Karaman (2013) ve Kargın, Ergül, Büyüköztürk ve Güldenoğlu (2015) tarafından yapılan çalışmalarda çocukların okuryazarlık gelişiminin daha özel bir alan içerisinde incelendiği göze çarpmaktadır. Yapılan pek çok çalışmanın sonuçları çocukların ilkokula başladıklarında okuryazarlık düzeyi açısından farklı özelliklere sahip olduklarını göstermekledir (Aram ve Biron, 2004; Erkan, 2011; Riley, 2006; Whitehurst ve Lonigan, 1998).

Bu noktadan hareketle bu araştırmanın temel amacı ilkokula yeni başlayan öğrencilerin okuryazarlık gelişimlerini belirlemeye yönelik bir aracın geliştirilmesidir.

Araştırmanın temel amacı doğrultusunda aşağıdaki sorulara cevap aranmıştır. Belirleme aracınin;

1) Temel Görsel Alg1

2) Dinleme, İzleme ve Anlama

3) Görsel Okuma ve Anlama

4) Sesbilgisel Farkındalık

5) Yazı Farkındalığı ve

6) Temel Yazma Becerileri Testlerinin
a. Geçerliği
b. Güvenirliği nedir?

Yöntem

60 - 84 ay aralığındaki çocukların okuryazarlık gelişimlerini değerlendirmek amacıyla bir aracın oluşturulmasını hedefleyen bu çalışma, nicel araştırmanın yapısına uygun 
olarak ölçek geliştirme mahiyetinde tarama modelinde planlanmıştır (Karasar 2009, s. 77).

\section{Çalışma Grubu}

Araştırmanın çalışma evrenini Sivas İl merkezinde Millî Eğitim Bakanlığına bağlı ilkokulların birinci sınıflarına devam eden 60 - 84 ay aralığında bulunan öğrenciler oluşturmaktadır. Araştırma sürecinde aracın ön uygulaması için “Ön Uygulama Grubu" belirlenmiştir. Aracın nihai formunun uygulanması için "Üç Aşamalı Örnekleme" yöntemi kullanılarak örneklem oluşturulmuştur.

Ön uygulama grubu. Araştırmada oluşturulan aracın ön uygulaması okul öncesi dönemin son aşamasında olan (Mayıs/Haziran) ve Eylül ayı itibariyle ilkokula başlayacak olan 64 okul öncesi öğrencisiyle yapılmıştır. Ön uygulama grubunda yer alan 64 öğrencinin 31'i kız, 33'ü erkektir.

Örneklem. Araştırmanın örnekleminin belirlenmesi üç aşamada tamamlanmıştır. Birinci aşamada "tabakalı örnekleme", ikinci aşamada "basit seçkisiz örnekleme" ve üçüncü aşamada "uygun örnekleme" yöntemi kullanılarak katılımcılar belirlenmiştir.

Birinci aşamada, Türkiye İstatistik Kurumunun (TUİK) Sivas il merkezindeki sokak ve caddelerin gelişmişlik düzeyleri ile ilgili verileri doğrultusunda bir sınıflandırma yapılarak düşük, orta ve yüksek sosyo-ekonomik düzeyde bulunan okullar belirlenmiştir. İkinci aşamada seçkisiz örnekleme yöntemi kullanılarak sosyoekonomik düzeye göre sınıflandırılan ilkokullar arasından madde sayısına uygun sayıda ilkokul seçkisiz olarak belirlenmiştir. Seçilen okulların sosyo-ekonomik düzeyi hakkında okul yöneticilerinden bilgi alınmış, bu bilgilerin TÜİK'ten elde edilen verilerle uyum sağladığı görülmüştür. Üçüncü aşamada uygun örnekleme yöntemi kullanılarak sınıflar ve bireyler belirlenmiştir. Belirlenen ilkokulların yöneticileri ve sınıf öğretmenleri ile yapılan görüşmeler sonucunda farklı ana diline sahip öğrenciler ve özel gereksinimli öğrenciler uygulama dışında bırakılmıştır. Normal gelişim gösteren ve ana dili Türkçe olan öğrenciler araştırmanın örneklemini oluşturmuştur. Örneklem 397 k1z ve 384 erkek olmak üzere 781 birinci sinıf öğrencisinden oluşmaktadır. Örneklemde yer alan öğrenciler 60-84 ay aralığında bulunmaktadır. Öğrencilerin 311'i okul öncesi eğitim almamış, 470'i ise okul öncesi eğitim almıştır. Örneklemde yer alan öğrencilerin 305'i düşük, 209'u orta ve 267'si yüksek sosyoekonomik düzeyden gelen öğrencilerdir.

\section{Veri Toplama Araçları}

$\mathrm{Bu}$ bölümde oluşturulan aracın geliştirilme süreci ifade edilerek tanıtımı yapılmış, analizlerine ilişkin sonuçlar bulgular kısmında ayrıntılı olarak ifade edilmiştir.

Erken Okuryazarlık Gelişimini Belirleme Aracı (EGBA) iki ayrı form ve dört ekten oluşmaktadır. Birinci form uygulayıcının yönergeleri takip edebilmesi ve ilgili puanlamanın yapılabilmesi için oluşturulan "Uygulayıc1 Kitapçı̆̆ı" dır. İkinci form test maddelerine ilişkin görsellerden oluşan "Uygulama Materyali" dir. Eklerde ise uygulama sürecinde öğrenciye sunulan hikâye kitabı, olay sıralama kartları, örgü ve şekilleri kopya etme sayfası ve harfleri yazma sayfası yer almaktadır. EGBA'nın geliştirme sürecine ilişkin bilgiler bu bölümde sunulmuş, ölçme aracının psikometrik özelliklerine ise araştırma bulgularında yer verilmiştir. 
İlkokula yeni başlayan çocukların okuryazarlık gelişimlerini gözlemlemek, incelemek, takip etmek ve değerlendirmek amacıyla bir aracın oluşturulmasını hedefleyen bu çalışmada, aracın geliştirilme sürecinde şu adımlar takip edilmiştir; 1) Testin Genel Amacının Belirlenmesi 2) Testte Ölçülecek Niteliklerin Belirlenmesi 3) Testte Ölçülecek Niteliklerin Tanımlanması ve Göstergelerin Belirlenmesi 4) Belirlenen Göstergelere Yönelik Deneme Maddelerinin Yazılması 5) Deneme Maddelerinin Gözden Geçirilmesi 6) Testin Ön Uygulama Formunun Uygulanması 7) Ön Uygulama Sonuçlarından Madde Analizi Yaparak Maddelerin Seçilmesi 8) Esas Uygulamaya Yönelik Testin Nihai Formunun Oluşturulması 9) Aracın Nihai Formunun İstatistiklerinin Kestirilmesi aşamaları gerçekleştirilmiştir (Atılgan, Kan ve Doğan, 2009; Baykul, 2010; Erkuş, 2012; Özçelik, 2010; Şeker ve Gençdoğan, 2006; Turgut ve Baykul, 2010).

EGBA kapsamında ölçülecek niteliklerle ilgili tanımlamalar ve göstergeler Tablo 1'de sunulmuştur.

Tablo 1

EGBA Kapsamında Yer Alan Alt Testlere Yönelik Tanımlar ve Göstergeler

\begin{tabular}{|c|c|c|}
\hline Test & Tanımlar & Göstergeler/Kaynaklar \\
\hline 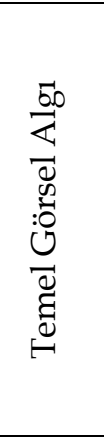 & $\begin{array}{l}\text { Görsel algı, görsel } \\
\text { uyaranları tanıma, } \\
\text { ayırt etme ve daha } \\
\text { önceki deneyimlerle } \\
\text { ilişkili olarak } \\
\text { yorumlama yeteneği } \\
\text { olarak tanımlanmıştır. }\end{array}$ & $\begin{array}{l}\text { Aynı olan resimleri fark edebilme, Farklı olan resimleri fark ayırt } \\
\text { edebilme, İlişkili olan resimleri tespit edebilme, Resmi tamamlayan } \\
\text { parçayı bulabilme, Kopya etme, Renkleri tanıma, Renkleri eşleştirme } \\
\text { (Akyol, 2007; Apak, 1990; Arıök, 2001; Brown, Rodger ve Davis, } \\
\text { 2003; Colarusso ve Hammil, 1972; Dönmez, 2000; Frostig, Lefever ve } \\
\text { Whittlesey, 1961; Hammil, Pearson, Voress 1993; Kavale ve Forness, } \\
\text { 2000; Mangır, Çağatay- Aral, 1987; MEB, 2013: MEGEP, 2007; Memiş } \\
\text { ve Sivri, 2016; Metin ve Aral, 2013; Kalkan ve Arslan, 2015; Oktay, } \\
\text { 2010; Tuğrul, Aral, Erkan ve Etikan, 2001; Waugh ve Watson, 1970; } \\
\text { Zhou, McBride-Chang ve Wong, 2014) }\end{array}$ \\
\hline 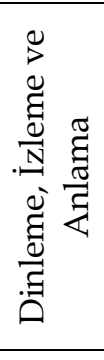 & $\begin{array}{l}\text { Dinleme, izleme ve } \\
\text { anlama becerileri } \\
\text { bireyin işittiğini } \\
\text { kavraması, dinlediğini } \\
\text { anlaması ve } \\
\text { yorumlaması olarak } \\
\text { tanımlanabilmektedir. }\end{array}$ & $\begin{array}{l}\text { Yönergeleri takip edebilme, Kavramların eş/zıt anlamın ifade } \\
\text { edebilme, Dinlediklerini kavrayabilme, Dinlediğinden sonuçlar } \\
\text { çlkarabilme, Dinlediğini hatırlayabilme, Dinlediğini anlayabilme, } \\
\text { Dinlediğini uygulayabilme (Akyol, 2007; Bostorm, 2011; Cooper } \\
\text { 1997; Doğan, 2011; Garner ve Bochna, 2004; Güneş, 2007; Güneş, } \\
\text { 2014; MEB, 2013; MEGEP, 2007; Oktay,2010; Özbay, 2005; Özbay, } \\
\text { 2005; Richards, 1983; Wolwin ve Coakley 2000; Woodcock, McGrew, } \\
\text { Mather ve Schrank, 2001) }\end{array}$ \\
\hline 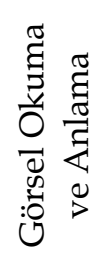 & $\begin{array}{l}\text { Görsel okuma bireyin } \\
\text { görselleri tanıma, } \\
\text { anlama ve yorumlama } \\
\text { becerisi olarak } \\
\text { tanimlanabilmektedir. }\end{array}$ & $\begin{array}{l}\text { Görselleri tanıyabilme, ayırt edebilme ve ayrıntıları fark edebilme, } \\
\text { Kelimenin/cümlenin görsel karşılığını tespit edebilme Görsellerden } \\
\text { yararlanarak soruları cevaplayabilme, Görselleri oluş sırasına göre } \\
\text { sıralayabilme (Akyol, 2007; Avgerinou ve Ericson, 1997; Baş ve Örs, } \\
\text { 2015; Çam, 2010; Debes, 1968; Ford, 2010; Güneş, 2014; MEB, 2009; } \\
\text { MEB, 2013; MEGEP, 2007; Oktay, 2010; Sinatra, 1986; Wileman, 1993) }\end{array}$ \\
\hline
\end{tabular}




\begin{tabular}{|c|c|c|}
\hline 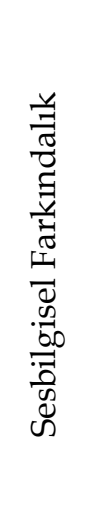 & $\begin{array}{l}\text { Sesbilgisel farkındalık; } \\
\text { kelime, hece, ilk ses - } \\
\text { son ses ve ses birim } \\
\text { farkındalığı ve bu alt } \\
\text { becerilere yönelik } \\
\text { sayma, tanıma, } \\
\text { birleştirme, bölme, } \\
\text { silme ve değiştirme } \\
\text { görevleridir }\end{array}$ & $\begin{array}{l}\text { Uyaklı Dizileri Fark Etme, Uyaklı Kelimeleri Eşleştirme, Aynı Ses ile } \\
\text { Başlayan Kelimeleri Eşleştirme, Sese Uygun Kelime Üretme, } \\
\text { Kelimenin İlk Sesini Silme, Kelimenin Son Sesini Silme, Kelimenin } \\
\text { İlk Sesini Değiştirme, Kelimenin Son Sesini Değiştirme, Kelime } \\
\text { Birleştirme, Hece Birleştirme, Ses Birleştirme, Kelime Ayırma, Hece } \\
\text { Ayırma, Ses Ayırma (Armbruster, Lehr ve Osborn, 2003; Bauserman, } \\
\text { 2008; Bayraktar ve Temel, 2014; Beauchat, Blamey ve Walpole 2010; } \\
\text { Bentin ve Leshem, 1993; Cisero, 1993; Erdoğan, 2009; Erdoğan, 2011; } \\
\text { Goswami ve Bryant, 1990; Gökkuş, 2016; Justice ve Pullen 2003; Kim, } \\
\text { Kim ve Lee, 2007; Konza, 2011; Schuele ve Boudreau, 2008; Torgesen } \\
\text { ve Mathes, 1998; Treiman ve Zukowski, 1991; Turan ve Akoğlu, } \\
\text { 2011; Vellutino ve Scanlon, 1987) }\end{array}$ \\
\hline 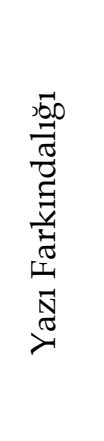 & $\begin{array}{l}\text { Kitap düzenlemeleri, } \\
\text { yazı düzenlemeleri ve } \\
\text { yazının işlevlerine } \\
\text { yönelik bilgidir. }\end{array}$ & $\begin{array}{l}\text { Kitapların oluşturuluş amaçlarını, kullanma biçimini ve kitapların } \\
\text { organizasyonunu anlama, Yazının nasıl düzenlendiğini anlamay1 } \\
\text { kolaylaştıran becerileri fark etme, Kelimelerinin ve harflerin } \\
\text { isimlendirebileceğinin ve anlam taşıdığın fak etme, Kelime ve } \\
\text { harflerin rakam veya karalama gibi diğer metin türlerinden farklı } \\
\text { olduğunu kavrama (Badian, 2001; Bayraktar, 2014; Bradley ve } \\
\text { Byrant, 1983; Foulin, 2005; Justice ve Ezell, 2001; Justice ve Ezell, } \\
\text { 2002; Kame'enui, Adams ve Lyon, 2002; Lassonde 2001; Lonigan ve } \\
\text { Whitehurst, 1998; Sénéchal ve LeFevre, 2002; Stewart ve Lovelace, } \\
\text { 2006; Şimşek, 2012) }\end{array}$ \\
\hline 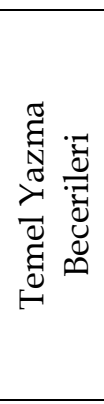 & $\begin{array}{l}\text { Temel yazma becerisi } \\
\text { küçük kas becerilerine } \\
\text { dayalı olarak } \\
\text { yazmanın fiziksel } \\
\text { unsurlarını yerine } \\
\text { getirebilme, örgü ve } \\
\text { şekil çizebilme ve } \\
\text { harfleri yazabilme } \\
\text { becerisidir. }\end{array}$ & $\begin{array}{l}\text { Çizgileri Bileştirme, Çizgileri Kopya etme, Örgü ve şekilleri kopya } \\
\text { etme, Harfleri yazma, Uygun oturma şekli, kâğıt tutma, bilek } \\
\text { duruşu, kalem tutma, kâğıt ile göz arasındaki mesafe, Soldan sağa } \\
\text { doğru yazma, yukarıdan aşağı doğru yazma (Akyol, 2012; Badian } \\
\text { 2000; Badian, 2001; Bayraktar, 2014; Bradley ve Byrant, 1983; } \\
\text { Falconer 2010; Foulin, 2005; Justice ve Ezell, 2001; Justice ve Ezell, } \\
\text { 2002; Lonigan ve Whitehurst, 1998; Morrow, 2007; Ratzon, Efraim ve } \\
\text { Bart, 2007; Sénéchal ve LeFevre, 2002; Svant, 2016; Şimşek, 2012) }\end{array}$ \\
\hline
\end{tabular}

EGBA kapsamında yer alan tüm testlerde görsellerden yararlanılmıştır. Testlerin uygulanacağı örneklemin gelişim özellikleri dikkate alınarak, sorunun biçimi ve cevap kaynağı açısından çoktan seçmeli ve doğru-yanlış olarak cevap verilebilecek görselli seçenekler düzenlenmiştir. Test maddelerine yönelik soru tipleri belirlenirken, örneklemden toplanacak veri üzerinde yapılacak analiz çalışmaları göz önüne alınarak doğru cevap için bir, yanlış cevap için sıfır kodlanabilecek bir yapı oluşturulmuştur. Madde yazımında yukarıda ifade edilen çalışmalar uygulanarak 395 madde oluşturulan madde havuzuna alınmıştır. Madde güçlüğü ve madde ayırt edicilik varsayımlarını karşılamayan maddeler çıkarıldıktan sonra EGBA kapsamında 269 madde ile araştırmaya devam edilmiştir. Aracın nihai formunda Temel Görsel Alg1 Testine yönelik 32; Dinleme, İzleme ve Anlama Testine yönelik 28; Görsel Okuma ve Anlama Testine yönelik 33; Sesbilgisel Farkındalık Testine yönelik 125; Yazı Farkındalığı Testine 24; Temel Yazma Becerileri Testine yönelik 27 madde yer almaktadır.

EGBA'nın uygulayıcı kitapçığı. EGBA'da yer alan testlerin uygulayıcı formları bir kitapçık halinde bir araya getirilmiştir. Ortaya çıkan kitapçık 48 sayfadan oluşmaktadır. Uygulama kitapçı̆̆ı uygulayıcının süreçte takip edeceği adımları açıklamakta, testlere ilişkin yönergeleri kapsamakta ve kitapçıkta testlere ilişkin kodlama yapılacak puanlama tabloları yer almaktadır. Uygulayıcı kitapçığı, uygulama 
formları ve ekler uygulama sürecinde birlikte kullanılan materyallerdir. Bundan dolayı uygulayıcı kitapçığında ilgili test başlı̆̆ı altında hangi materyalin kullanılacağı ve testin uygulama kitapçığındaki sayfası belirtilmiştir. Testinin ilk sayfasında testin tanıtımı, kitapçı̆̆ın kullanımı, uygulama sürecinde dikkat edilmesi gereken genel kurallar, başlama ve bitiş saati ve testin toplam puanına ilişkin "Puanlama Tablosu" yer almaktadir.

EGBA'nın uygulama materyali. Uygulama materyali toplam 54 sayfadan oluşturulmuş, A4 ebadında, 135 gram mat kuşe kâğıt üzerine renkli baskı uygulanmış görsellerden oluşan, spiral cilt ile bir araya getirilmiş bir materyaldir.

EGBA'nın uygulama ekleri. Uygulama ekleri kapsamında bir hikâye kitabı, dört adet olay sıralama kartı, renk kartları, kopya etme çalışması ve harf yazma sayfası yer almakladır. Uygulama eklerinin hangi çalışmada ve nasıl kullanılacağı uygulayıcı kitapçığında ifade edilmektedir. Uygulayıcı araçta yer alan testleri uygularken süreçte hangi materyali kullanacağını uygulayıcı kitapçığından takip edebilmektedir.

EGBA'da yer alan çalişmalarda öğrencilerden beklenenin ne olduğu anlatılmakta ve deneme maddesi üzerinde açıklama yapılabilmektedir. Örnek maddede eğer öğrenciden yanlış cevap alınmışsa ya da cevap alınamamışsa uygulayıcı tarafından açıklama yapılabilmektedir. Deneme maddeleri üzerinde yapılan uygulamalarda cevap alma zamanı hakkında bir kısıtlama bulunmamakta ancak test maddelerinde öğrencilerden birkaç saniye içerisinde cevap vermeleri beklenmektedir. Cevap alınamadığında ise yansız tepkiler verilerek bir sonraki maddeye geçilmektedir.

Temel görsel algı (TGA) testi. İlkokula başlayan çocukların görsel algı becerilerini değerlendirmeye yönelik 4 deneme maddesi ve 17 test maddesi olmak üzere 21 maddeden oluşmaktadır. Bu maddeler aynı olanı bulma (4 madde), faklı olanı bulma (4 madde), ilişkili olanı bulma (5 madde) ve resmi tamamlayan parçayı bulma (4 madde) başlıkları altında sınıflandırılmıştır.

Dinleme/izleme ve anlama (DİA) testi. İlkokula başlayan çocukların dinleme, takip etme, izleme ve anlama becerilerini değerlendirmeye yönelik 3 deneme maddesi ve 20 test maddesi olmak üzere 23 maddeden oluşmaktadır. Bu maddeler yönergeleri takip etme (5 madde), kelimenin karşıt anlamını bulma (10 madde) ve hikâye ögelerini bulma (5) başlıkları altında sınıflandırılmıştır.

Görsel okuma ve anlama (GOA) testi. Illkokula başlayan çocukların görselleri, tanıma, anlamlandırma ve anlama becerilerini değerlendirmeye yönelik 3 deneme maddesi ve 14 test maddesinden oluşmaktadır. Bu maddeler, nesne tanıma (4 madde), ifadenin görsel karşılığını bulma (6 madde) ve olay sıralama (3 madde) başlıkları altında sınıflandırılmıştır.

Sesbilgisel farkındalık (SF) testi. İlkokula başlayan çocukların ses benzerliklerini fark etme, sesleri tanıma, sesleri birleştirme ve sesleri ayırma becerilerini değerlendirmeye yönelik 16 deneme maddesi ve 53 test maddesinden oluşmaktadır. Bu maddeler;

- Uyaklı Dizileri Fark Etme (6 madde)

- Uyakli Kelimeleri Bulma (6 madde)

- Aynı Ses ile Başlayan Kelimeleri Bulma (7 madde)

- Sese Uygun Kelime Üretme (7 madde)

- Hece Birleştirme (7 madde) 
- Ses Birleştirme (7 madde)

- Kelime Ayırma (7 madde)

- Hece Ayırma (6 madde) başlıkları altında sınıflandırılmıştır.

Yazı farkındalığı (YF) testi. İlkokula başlayan çocukların yazı farkındalığı becerilerini değerlendirmeye yönelik 2 deneme maddesi ve 15 test maddesinden oluşmaktadır. Bu maddeler kitap kavramlarını tanıma (6 madde) ve yazı kavramlarını tanıma (9 madde) başlıkları altında sınıflandırılmıştır.

Temel yazma becerileri (TYB) testi. İlkokula başlayan çocukların temel yazma becerilerini değerlendirmeye yönelik 2 deneme maddesi ve 16 test maddesinden oluşmaktadır. Bu maddeler, örgü ve şekilleri kopya etme (9 madde) ve harf yazma (7 madde) başlıkları altında sınıflandırılmıştır.

Erken Okuryazarlık Gelişimini Belirleme Aracının (EGBA) uygulayıcı kitapçığı, uygulama formları ve ekleri Şekil 1'de sunulmuştur.

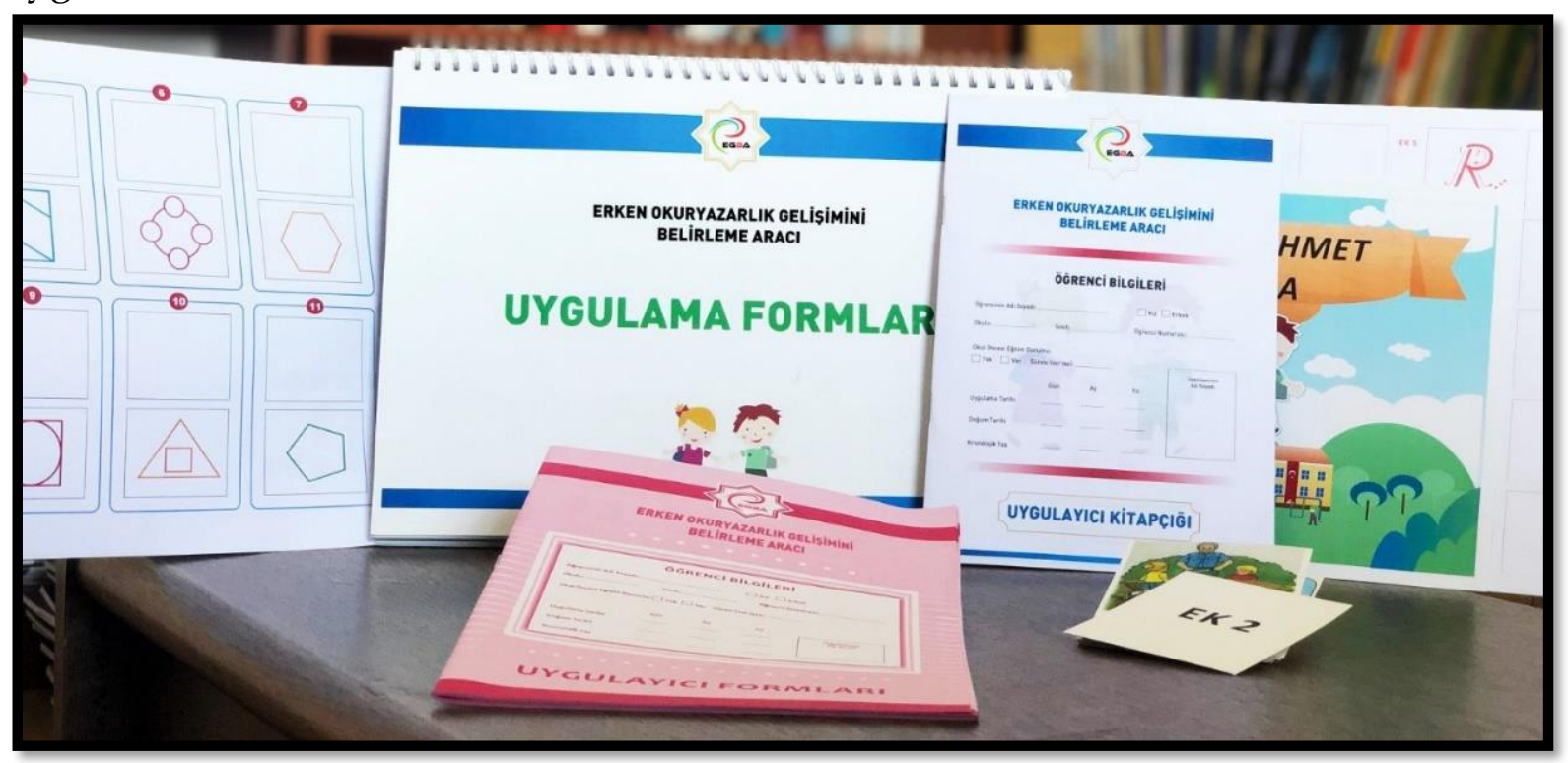

Şekil 1. Erken okuryazarlık gelişimini belirleme aracı (EGBA)

\section{Veri Toplama Süreci}

Araştırmanın veri toplama sürecinde, örneklemde yer alan öğrencilere EGBA uygulayıcı grubu tarafından bireysel olarak uygulanmıştır.

Uygulayıcı grubunun belirlenmesi ve eğitimi. Aracın nihai formunun uygulanmasında Zaman/Uygulama Süresi/Örneklem sayısı göz önüne alınarak Sınıf Öğretmenliği lisans programında öğrenim gören 3. Sınıf öğrencilerinden 15 kişilik uygulayıcı grubu belirlenmiştir. Grubun belirlenmesinde gönüllülük esası temel alınmış ve gönüllü olarak katılmak isteyenlere eğitim verilmiştir.

Deneme uygulaması ve ön uygulama. İlk aşamada deneme uygulaması olarak iki araştırmacı tarafından ikişer öğrenciye EGBA'da yer alan testler uygulanmıştır. Deneme uygulamasının ikinci kısmında uygulayıcı grubuna örnek uygulama çalışmaları yaptırılmıştır. Bu doğrultuda Sivas A ilkokulunda yer alan 15 öğrenci ile her bir uygulayıcı birer örnek uygulama gerçekleştirmiştir. Bu süreçte iki araştırmacı uygulayıcıları gözlemlemiş, uygulama sonrasında uygulayıcı grubu ile yapılan toplantıda gözlemler paylaşılmıştır. 
Ön uygulama Milli Eğitim Müdürlüğünden alınan izinler doğrultusunda altı farklı ilkokulda gerçekleştirilmiştir. Ön uygulama grubunda 64 öğrenci yer almaktadır ve 2015 yılının mayıs ayının son haftasında gerçekleştirilmiştir.

Esas uygulama. Esas uygulamada, ön uygulama sonucunda ortaya çıkan EGBA'nın nihai formu örnekleme uygulanmıştır. Uygulamalara başlamadan önce, çalışma yapılacak okullara araştırmacı ve uygulayıcılar tarafından ziyarette bulunularak çalışmanın amacı, kapsamı ve içeriği hakkında bilgi verilmiştir. Ön uygulama sürecinde olduğu gibi, uygulayıcıların ve öğrencilerin rahatça çalışabilecekleri ortamların düzenlenmesi gerektiği okul yönetimleri ile paylaşılmış ve uygun olan alanlarda (kütüphane, boş derslikler, laboratuvarlar, boş odalar) çalışma ortamları oluşturulmuştur. Çalışma alanlarının belirlenmesinde 1sı, ses ve aydınlatma açılarından uygun alanların seçilmesine dikkat edilmiştir. Uygulama alanları oluşturulduktan sonra sınıf öğretmenleri ile çalışma hakkında bilgi paylaşımı yapılmıştır. Uygulamalar 2015 yılının Eylül ve Ekim ayları süresince gerçekleştirilmiştir. Esas uygulamada 800 öğrenci ile bireysel çalışma yapılmıştır. Bu Uygulama süreci sonunda ortaya çıkan test süreleri Tablo 2'de sunulmuştur.

Tablo 2

Ön Uygulama Sürecinde EGBA'nin Test Süreleri

\begin{tabular}{lccccc}
\hline Testin Adı & $\begin{array}{c}\text { Madde } \\
\text { Sayısı }\end{array}$ & $\begin{array}{c}\text { Kn } \\
\text { Küra } \\
\text { Sür.) }\end{array}$ & $\begin{array}{c}\text { En Uzun } \\
\text { Süre (dk.) }\end{array}$ & $\begin{array}{c}\text { Ortalama } \\
\text { (dk.) }\end{array}$ & $\begin{array}{c}\text { Madde Başına } \\
\text { Ortalama Süre (dk.) }\end{array}$ \\
\hline Temel Görsel Alg1 & 32 & 2 & 10 & 5.16 & 0.21 \\
\hline Dinleme. İzleme ve Anlama & 28 & 2 & 9 & 4.95 & 0.20 \\
\hline Görsel Okuma ve Anlama & 33 & 3 & 13 & 5.81 & 0.21 \\
\hline Sesbilgisel Farkındalık & 125 & 13 & 48 & 24.00 & 0.20 \\
\hline Yazı Farkındalığ1 & 24 & 3 & 10 & 4.82 & 0.21 \\
\hline Temel Yazma Becerileri & 27 & 6 & 15 & 9.72 & 0.36 \\
\hline Toplam & 269 & 29 & 81 & 54.46 & 0.21 \\
\hline
\end{tabular}

Tablo 2'de ifade edildiği üzere, EGBA'nın ortalama uygulama süresi 54,46 dakikadır. Uygulama sürecinde en uzun süre 81 dakika, en kısa süre 32 dakika olarak tespit edilmiştir.

\section{Verilerin Analizi}

EGBA'dan elde edilen verilerin analizi üç aşamada gerçekleşmiştir; Birinci aşamada EGBA'nın alt testlerinden ve tamamından elde edilen puanların betimsel istatistikleri belirlenmiştir. İlk inceleme sonucunda 781 kişiden alınan verinin sağlıklı ve değerlendirmeye alınabilir olduğu görülmüştür. Ulaşılan verilerin en düşük ve en yüksek puanı, ortalama puanı, standart sapması, çarpıklık ve basıklık katsayısı değerleri hesaplanmıştır. Elde edilen toplam puanların normal dağılım gösterip göstermediği incelenmiştir ve EGBA'nın alt testlerinin geçerlik, güvenirlik ve madde analizi çalışmaları yapılmıştır. Kapsam geçerliği çalışmalarında Lawshe (1975) 
tarafından geliştirilen ve ismiyle anılan Lawshe tekniği kullanılmıştır. Yapı geçerliği çalışmalarında her alt teste ilişkin açımlayacı faktör analizi ve doğrulayıcı faktör analizi çalışmaları uygulanmıştır (Büyüköztürk, 2010; Seçer, 2013; Tavşanc1l, 2010). Testlerde yer alan maddelerin iki kategorili $(1,0)$ olarak puanlanmasindan dolayı alt testlere yönelik uygulanan faktör analizi çalışmalarında tetrakorik korelasyon matrisi üzerinden çalışılmıştır (Baykul, 1999; Çokluk, Şekercioğlu ve Büyüköztürk, 2012). Güvenirlik çalışmaları kapsamında KR20 iç tutarlık ve iki yarı test güvenirliği çalışmaları yapılmıştır. Madde analizi kapsamında madde güçlüğü ve nokta çift serili korelasyon katsayısı hesaplanmıştır. Buna ek olarak \%27'lik alt ve üst gruplar arasında t-Testi uygulanarak gruplar arasındaki farklar incelenmiştir. İfade edilen değerlerin hesaplanmasinda ISTATISCA, XL-STAT, FACTOR 9.0, JMETRIC ve SPSS 18 programlarından yararlanılmıştır.

\section{Bulgular}

Erken Okuryazarlık Gelişimini Belirleme Aracının (EGBA) geçerlik çalışmaları kapsamında kapsam ve yapı geçerliği çalışmaları yapılmıştır. Güvenirlik ve madde analizi çalışmaları kapsamında KR-20 iç tutarlık katsayısı ve İki Yarı Test Güvenirliği katsayıları hesaplanmıştır. Madde analizi çalışmaları kapsamında ise madde güçlüğü, nokta çift serili korelasyon katsayısı hesaplanmış ve \% $27^{\prime}$ lik alt ve üst gruplar arasında t-Testi uygulanmıştır.

\section{Kapsam Geçerliği Çalışmaları}

EGBA'nın alt testlerinin kapsam geçerliği çalışmaları bağlamında uzman görüşlerinden faydalanılmıştır. Uzman görüşüne başvurmadan önce, ilgili alan yazın detaylı bir şekilde taranmış, TGA testine yönelik 5 deneme ve 25 uygulama maddesi, DİA testine yönelik 5 deneme ve 25 uygulama maddesi, GOA testine yönelik 5 deneme ve 34 uygulama maddesi, SF testine yönelik 20 deneme ve 150 uygulama maddesi, YF testine yönelik 5 deneme ve 24 uygulama maddesi, TYB testine yönelik 2 deneme ve 29 uygulama maddesi yazılmıştır. İlk uzman görüşü sonucunda TGA, DİA, SF, YF, GOA ve TYB testlerinin madde sayılarında bir değişiklik olmamakla birlikte maddelerin görsellerinde çeşitli düzenlemeler önerilmiş (TGA testinde aob1-2-5, fob34, fb4-5; DİA testinde dia1-6-9-13-18-21-22-23; GOA testinde gkb1-2-3-6-11-19, nt1-2-35; SF testinde udf16-17-18-22-25-19, uke31-32-35-38-43-45) ve deneme maddelerinin hangilerinin olacağ değerlendirildikten sonra ortaya çıkan form 11 uzmana tekrar sunulmuştur. İkinci uzman görüşünden alınan sonuçlara Lawshe tekniği uygulanarak maddelerin KGO değerleri belirlenmiştir. İkinci uzman görüşünden geçen maddelerin KGO değerleri Tablo 3'te ifade edilmiştir.

Tablo 3'te ifade edildiği üzere Veneziano ve Hooper (1997) tarafından belirlenen KGO referans tablosuna göre 11 kişilik uzman heyetinden alınan görüşler için bir maddenin en az 0,59 KGO değerine sahip olması gerekmektedir. Tabloda ifade edilen bulgular incelendiğinde maddelerin KGO değerlerinin bu değerin üzerinde olduğu görülmektedir. Bu doğrultuda maddelerin KGO değerlerinin 0.82 - 1.00 aralığında değişim gösterdiği göz önüne alındığında EGBA'da yer alan test maddelerinin kapsam geçerliğini sağladığı ifade edilebilir. 
Tablo 3

EGBA'nın Alt Testlerinin Kapsam Geçerlik Oranlarına İlişkin Bulgular

\begin{tabular}{lcccc}
\hline Alt Test & Uzman Sayısı & Madde Sayısı & KGO & Referans Aralığı \\
\hline Temel Görsel Algı (TGA) & 11 & 25 & $0.82-1.00$ & $0.59-1.00$ \\
\hline Dinleme. İzleme ve Anlama (DİA) & 11 & 25 & $0.82-1.00$ & $0.59-1.00$ \\
\hline Görsel Okuma ve Anlama (GOA) & 11 & 34 & $0.63-1.00$ & $0.59-1.00$ \\
\hline Sesbilgisel Farkındalık (SF) & 11 & 150 & $0.63-1.00$ & $0.59-1.00$ \\
\hline Yazı Farkındalığı (YF) & 11 & 24 & $0.82-1.00$ & $0.59-1.00$ \\
\hline Temel Yazma Becerileri (TYB) & 11 & 25 & $0.82-1.00$ & $0.59-1.00$ \\
\hline
\end{tabular}

\section{Açımlayıcı Faktör Analizi Sonuçları}

Esas uygulamada ulaşılan 781 öğrenciden elde edilen veriler üzerinde açımlayıcı faktör analizi çalışması yapılmıştır. Açımlayıcı faktör analizi uygulamasından önce, örneklem büyüklüğünün faktörleşmeye uygunluğunu test etmek amaciyla KaiserMeyer-Olkin (KMO) testi uygulanmıştır. Analiz sonucunda testlerin KMO değerlerinin 0.80 üzeri olduğu belirlenmiştir. Bu bulgu örneklem büyüklüğünün faktör analizi yapmak için yeterli (Field, 2009; Hutcheson ve Sofroniou, 1999) olduğunu göstermektedir. Ayrıca verilerin çok değişkenli normal dağılımdan gelip gelmediğini belirlemek amacıyla Bartlett Sphericity testi uygulanmıştır. Bartlett küresellik testi sonuçları incelendiğinde, elde edilen ki-kare değerlerinin manidar olduğu görülmüştür. Verilerin faktör analizi için uygunluğunda KMO değerinin 1'e yaklaşması (Tavşancıl, 2010) ve Bartlett testinin anlamlı çıkması (Büyüköztürk, 2010; Kalayc1, 2010) istenen bir durumdur. Bu doğrultuda verilerin çok değişkenli normal dağılımdan geldiği kabul edilmiştir. KMO ve Bartlett Sphericity testi değerlerine göre elde edilen verilerin faktör analizi çalışmasına uygun olduğu sonucuna ulaşılmıştır. Tablo 4 'te ifade edilen değerler sunulmuştur.

Tablo 4

EGBA Kapsamında Yer Alan Testlerin KMO ve Bartlett Testi Sonuçlarn

\begin{tabular}{lcccccc}
\hline Parametre & TGA & DİA & GOA & SF & YF & TYB \\
\hline KMO Testi & 0.80 & 0.93 & 0.75 & 0.93 & 0.81 & 0.84 \\
\hline Bartlett Testi & $\begin{array}{c}\mathrm{x}^{2}=1765 \\
\mathrm{p}=0.00\end{array}$ & $\begin{array}{c}\mathrm{x}^{2}=3970 \\
\mathrm{p}=0.00\end{array}$ & $\begin{array}{c}\mathrm{x}^{2}=777 \\
\mathrm{p}=0.00\end{array}$ & $\begin{array}{c}\mathrm{x}^{2}=1378 \\
\mathrm{p}=0.00\end{array}$ & $\begin{array}{c}\mathrm{x}^{2}=105 \\
\mathrm{p}=0.00\end{array}$ & $\begin{array}{c}\mathrm{x}^{2}=2194 \\
\mathrm{p}=0.00\end{array}$ \\
\hline Öz Değer & 4 & 1 & 3 & 8 & 2 & 1 \\
\hline A. Varyans & $\% 58.23$ & $\% 44.69$ & $\% 46.13$ & $\% 66.61$ & $\% 47.47$ & $\% 32.95$ \\
\hline
\end{tabular}

Tablo 4'te ifade edildiği üzere TGA testine yapılan analiz sonucunda, analize temel olarak alınan 25 madde için öz değeri 1'in üzerinde olan sekiz bileşen olduğu görülmüştür. Hiçbir faktöre yük vermeyen (aob1, fob1, rtbp2) ve binişik maddeler (fb1,2,3,4,5) çıkartıldığında maddelerin dört bileşen altında toplanabildiği görülmüştür. DİA testine yapılan analiz sonucunda, analize temel olarak alınan 25 
madde için öz değeri 1'in üzerinde olan dört bileşen olduğu görülmüştür. Hiçbir faktöre yük vermeyen maddeler (dia8, dia11, dia15, dia16, dia18) çıkartıldığında maddelerin bir faktör altında toplanabildiği görülmüştür. GOA testine yapılan analiz sonucunda, analize temel olarak alınan 39 madde için öz değeri 1'in üzerinde olan altı bileşen olduğu görülmüştür. Hiçbir faktöre yük vermeyen (ba1,ba2,ba5,rt5,gkb1,4,5,6,18,19,os2) ve binişik maddeler (gkb7,8,9,11,12,14,17) çıkartıldığında maddelerin üç bileşen altında toplanabildiği görülmüştür. SF testine yapılan analiz sonucunda analize temel olarak alınan 125 madde için öz değeri 1'in üzerinde olan 18 bileşen olduğu görülmüştür. Hiçbir faktöre yük vermeyen ve binişik maddeler çıkartıldığında maddelerin 8 bileşen altında toplanabildiği görülmüştür. YF testine yapılan analiz sonucunda analize temel olarak alınan 24 madde için öz değeri 1'in üzerinde olan üç bileşen olduğu görülmüştür. Hiçbir faktöre yük vermeyen (kkt2, ykt21) ve binişik maddeler (kkt5, kkt9, kkt16, kkt17, kkt18, kkt19) çıkartıldığında maddelerin iki bileşen altında toplanabildiği görülmüştür. TYB testine yapılan analiz sonucunda analize temel olarak alınan 25 madde için öz değeri 1'in üzerinde olan üç bileşen olduğu görülmüştür. Hiçbir faktöre yük vermeyen (ke8, hf13) ve madde faktör yük değeri 0,30'un altında olan ya da binişik olan maddeler (ke2, ke11, hf14, hf20, hf21, hf22, hf24, hf25, hf27) çıkartıldığında maddelerin bir faktör altında toplanabildiği görülmüştür. Açıklanan varyans oranları TGA testi için \%58,23, DİA testi için \%44.69, GOA testi için \%46.13, SF testi için \%66.61, YF testi için \%47.47 ve TYB testi için \%32.95'tir. Yamaç-birikinti grafiğgindeki kırılma noktaları ve öz değerler ulaşılan faktör yapılarının testlerin geliştirilme sürecinde ön görülen bileşen sayısı ile uyumlu olması açısından anlamlı görülmektedir. Tabachnick ve Fidell (2007) öz değeri bir ve üzeri olan bileşenlerin varyansa önemli bir katkısının olduğunu belirtmektedir. Tablo 5 'te binişik ve kabul değerinin altında kalan maddeler çıkarıldıktan sonra ulaşılan faktör yük değerleri ve faktör sayıları sunulmuştur.

Tablo 5'te ifade edilen veriler incelendiğinde EGBA kapsaminda yer alan testlerin maddelerinin faktör yük değerlerinin ve madde sayılarının kabul edilebilir sınırlar içinde olduğu söylenebilir. TGA testinin varyansa \%31 katkı sağlayan birinci boyutu "aynı olanı bulma", \%10 katkı sağlayan ikinci boyutu "farklı olanı bulma", \%8.5 katkı sağlayan üçüncü boyutu "ilişkili olanı bulma” ve \%7.5 katkı sağlayan dördüncü boyutu "resmi tamamlayan parçayı bulma" olarak isimlendirilmiştir. DİA testinin \%44.69'unu açıklayan faktör "dinleme izleme ve anlama becerileri" olarak isimlendirilmiştir. GOA testinin varyansa \%11.66 katkı sağlayan birinci boyutu "nesne tanıma", \%25.81 katkı sağlayan ikinci boyutu "görsel karşılığını bulma" ve \%8.66 katk1 sağlayan üçüncü boyutu "olay sıralama" olarak isimlendirilmiştir. SF testinin varyansa \%26 katk1 sağlayan birinci boyutu "uyaklı dizileri fark etme", \%11 katk1 sağlayan ikinci boyutu "uyaklı kelimeleri eşleştirme", \%9 katkı sağlayan üçüncü boyutu "aynı ses ile başlayan kelimeleri eşleştirme", \%7 katkı sağlayan dördüncü boyutu "sese uygun kelime üretme", \%6 katkı sağlayan beşinci boyutu "hece birleştirme", \%6 katkı sağlayan altıncı boyutu "ses birleştirme", \%5 katkı sağlayan yedinci boyutu "kelime ayırma" ve \%5 katkı sağlayan sekizinci boyutu "hece ayırma" olarak isimlendirilmiştir. YF testinin varyansa \%34 katkı sağlayan birinci boyutu "yazı kavramlarını tanıma", \%13 katkı sağlayan ikinci boyutu "kitap kavramlarını tanıma" olarak isimlendirilmiştir. TYB testinde öngörülen teorik yapı çerçevesinde varyansın \%32.95'ini açılayan faktör "temel yazma becerileri" olarak isimlendirilmiştir. 
Tablo 5

Binişik ve Kabul Değerinin Altında Kalan Maddeler Çıkarıldıktan Sonra Ulaşılan Faktör Yük Değerleri ve Faktör Sayıları

\begin{tabular}{|c|c|c|c|c|c|c|c|c|c|c|}
\hline \multirow{2}{*}{$\begin{array}{l}\text { Alt } \\
\text { Test }\end{array}$} & \multirow{2}{*}{$\begin{array}{c}\text { Madde } \\
\text { Say1s1 }\end{array}$} & & \multicolumn{8}{|c|}{ Faktörler } \\
\hline & & & 1 & 2 & 3 & 4 & 5 & 6 & 7 & 8 \\
\hline \multirow{2}{*}{ TGA } & \multirow{2}{*}{17} & FYD & $\begin{array}{c}0.61- \\
0.82 \\
\end{array}$ & $\begin{array}{c}0.78- \\
0.86\end{array}$ & $\begin{array}{c}0.67- \\
0.84\end{array}$ & $\begin{array}{c}0.33- \\
0.82\end{array}$ & & & & \\
\hline & & MS & 4 & 4 & 5 & 4 & & & & \\
\hline \multirow{2}{*}{ DİA } & \multirow{2}{*}{20} & FYD & $\begin{array}{c}0.34- \\
0.86\end{array}$ & & & & & & & \\
\hline & & MS & 20 & & & & & & & \\
\hline \multirow[t]{2}{*}{ GOA } & \multirow[t]{2}{*}{15} & FYD & $\begin{array}{c}0.46- \\
0.68 \\
\end{array}$ & $\begin{array}{c}0.38- \\
0.59 \\
\end{array}$ & $\begin{array}{c}0.57- \\
0.62 \\
\end{array}$ & & & & & \\
\hline & & MS & 4 & 8 & 3 & & & & & \\
\hline \multirow[t]{2}{*}{ SF } & \multirow[t]{2}{*}{53} & FYD & $\begin{array}{c}0.41- \\
0.74 \\
\end{array}$ & $\begin{array}{c}0.52- \\
0.83 \\
\end{array}$ & $\begin{array}{c}0.56- \\
0.73 \\
\end{array}$ & $\begin{array}{c}0.56- \\
0.83 \\
\end{array}$ & $\begin{array}{c}0.77- \\
0.85 \\
\end{array}$ & $\begin{array}{c}0.79- \\
0.89 \\
\end{array}$ & $\begin{array}{c}0.89- \\
0.91 \\
\end{array}$ & $\begin{array}{c}0.71- \\
0.88 \\
\end{array}$ \\
\hline & & MS & 6 & 6 & 7 & 7 & 7 & 7 & 7 & 6 \\
\hline \multirow[t]{2}{*}{ YF } & \multirow[t]{2}{*}{15} & FYD & $\begin{array}{c}0.50- \\
0.89\end{array}$ & $\begin{array}{c}0.34- \\
0.78\end{array}$ & & & & & & \\
\hline & & MS & 9 & 6 & & & & & & \\
\hline \multirow[t]{2}{*}{ TYB } & \multirow[t]{2}{*}{16} & FYD & $\begin{array}{c}0.45- \\
0.64 \\
\end{array}$ & & & & & & & \\
\hline & & MS & 16 & & & & & & & \\
\hline
\end{tabular}

\section{Doğrulayıcı Faktör Analizi Sonuçları}

Açımlayıcı faktör analizi sonucunda ortaya çıkan faktör yapılarının geçerliğini test etmek amaciyla (Harrington, 2009; Tabachnick ve Fidell, 2007) ulaş1lan modele DFA uygulanmıştır. AFA sonucunda ortaya çıkan modellerin incelenmesinde ilk olarak maddelerin ortaya çıkan faktör yapısı ile uyum sağlayıp sağlamadığı değerlendirilmiş, belirlenen faktör yapısı altında her bir maddenin $t$-değerlerinin anlamlılı̆̆ sorgulanmıştır. Bu inceleme sonucunda testlerin AFA sonucunda ortaya çıkan yapılarında maddelerin ilgili faktörler altında anlamlı olduğu tespit edilmiştir. İkinci olarak ise her maddenin standart faktör yük değerleri incelenmiştir. İnceleme sonucunda standart faktör yük değerlerinin 0.30 ve üzerinde olduğu gözlemlenmiştir. Son olarak her bir test için ulaşılan modelin uyum değerleri incelenmiştir. Ulaşılan modelin uyum değerleri Tablo 6 ' da sunulmuştur.

Tablo 6' da ifade edilen DFA uyum değerleri incelendiğinde; ulaşılan değerlerin kabul edilebilir aralıklarla karşılaştırıldı ğında değerlerin kabul edilebilir sınırlar içinde olduğu söylenebilir. Madde faktör yük değerleri açısından TGA testinde yer alan maddelerin 0.36 ile 0.64 aralığında, DİA testinde yer alan maddelerin 0.30 ile 0.69 aralığında, GOA testinde yer alan maddelerin bir madde (m12:0.27) dişında 0.30 ile 0.55 aralığında, SF testinde yer alan maddelerin 0.56 ile 0.84 aralığında, YF testinde yer alan maddelerin 0,51 ile 0,81 aralığında ve TYB testinde yer alan maddelerin 0.30 ile 0.69 aralığında değişim gösterdiği belirlenmiştir. Sonuç olarak 17 madde ve 4 boyuttan oluşan TGA testinin, 20 madde ve 1 boyuttan oluşan DİA testinin, 14 madde ve 3 boyuttan oluşan GOA testinin, 53 madde ve 8 boyuttan oluşan SF testinin, 15 madde ve 2 boyuttan oluşan YF testinin ve 16 madde ve 1 boyuttan oluşan TYB testinin DFA 
uyum değerlerinin anlamlı olduğu ve testlerin açımlayıcı faktör analizinde ortaya çıkan yapılarının doğrulandığı ifade edilebilir.

Tablo 6

EGBA Kapsamında Yer Alan Testlerin DFA Sonucunda Ulaşılan Uyum Değerleri

\begin{tabular}{|c|c|c|c|c|c|c|c|c|}
\hline \multicolumn{2}{|c|}{ İncelenen Parametreler } & TGA & DİA & GOA & SF & YF & TYB & Referans Aralığı \\
\hline \multicolumn{2}{|c|}{ Modelin " $t$ " Değeri } & 0.05 & 0.05 & 0.05 & 0.05 & 0.05 & 0.05 & Anlamlı \\
\hline \multicolumn{2}{|c|}{ Faktör Yük Değerleri } & $\begin{array}{c}0.36- \\
0.64\end{array}$ & $\begin{array}{c}0.30- \\
0.69\end{array}$ & $\begin{array}{c}0.27- \\
0.55\end{array}$ & $\begin{array}{c}0.56- \\
0.84\end{array}$ & $\begin{array}{c}0.51- \\
0.81\end{array}$ & $\begin{array}{c}0.30- \\
0.69\end{array}$ & 0.30 Üzeri \\
\hline \multirow{7}{*}{$\begin{array}{l}\text { Model } \\
\text { Uyum } \\
\text { Değerleri }\end{array}$} & Ki-Kare/sd & 1.81 & 2.90 & 1.23 & 1.65 & 2.80 & 4.05 & $0 \leq X^{2} / s d \leq 3$ \\
\hline & RMSEA & 0.03 & 0.05 & 0.019 & 0.029 & 0.048 & 0.06 & $0.0 \leq \mathrm{RMSEA} \leq 0.05$ \\
\hline & GFI & 0.97 & 0.94 & 0.98 & 0.91 & 0.91 & 0.94 & $0.95 \leq \mathrm{GFI} \leq 1.00$ \\
\hline & AGFI & 0.96 & 0.93 & 0.98 & 0.90 & 0.90 & 0.92 & $0.95 \leq \mathrm{AGFI} \leq 1.00$ \\
\hline & SRMR & 0.038 & 0.04 & 0.029 & 0.05 & 0.058 & 0.05 & $0.00 \leq \mathrm{SRMR} \leq 0.05$ \\
\hline & NNFI & 0.96 & 0.97 & 0.98 & 0.99 & 0.90 & 0.91 & $0.95 \leq \mathrm{NNFI} \leq 1.00$ \\
\hline & CFI & 0.97 & 0.97 & 0.99 & 0.99 & 0.91 & 0.92 & $0.95 \leq \mathrm{CFI} \leq 1.00$ \\
\hline
\end{tabular}

\section{Güvenirlik ve Madde Analizi Bulguları}

EGBA kapsaminda yer alan TGA, DİA, GOA SF, YF ve TYB testlerinin güvenirlik çalışmaları kapsamında KR20 iç tutarlık ve iki yarı test güvenirliği katsayıları incelenmiştir. Madde analizi kapsamında madde güçlüğü, nokta çift serili korelasyon katsayıları ve \%27'lik alt ve üst gruplar arasında t-Testi sonuçları hesaplanmıştır.

Tablo 7

EGBA Kapsamında Yer Alan Testlerin Güvenirlik ve Madde Analizi Bulguları

\begin{tabular}{lccccccc}
\hline Uygulanan Analiz & TGA & DİA & GOA & SF & YF & TYB & Referans Değeri \\
\hline KR20 & 0.82 & 0.91 & 0.74 & 0.96 & 0.87 & 0.78 & $>0.70$ \\
\hline İki Yarı Test & 0.88 & 0.93 & 0.75 & 0.98 & 0.83 & 0.79 & \multirow{2}{*}{$>0.70$} \\
Güvenirliği & & & & & \\
\multirow{2}{*}{ Madde Güçlüğü } & $0.36-$ & $0.31-$ & $0.41-$ & $0.30-$ & $0.30-$ & $0.27-$ & \multirow{2}{*}{0.50 civarı } \\
& 0.91 & 0.85 & 0.88 & 0.68 & 0.79 & 0.67 & \multirow{2}{*}{0.29 ve üzeri } \\
\hline Nokta Çift Serili & $0.32-$ & $0.32-$ & $0.29-$ & $0.34-$ & $0.31-$ & $0.40-$ & \multirow{2}{*}{ Konlamlı } \\
Korelasyon Katsayısı & 0.56 & 0.70 & 0.49 & 0.62 & 0.60 & 0.52 & \multirow{2}{*}{ Alt-Üst G. “ $\mathrm{t}^{\prime \prime}$ Testi } \\
Sonuçları & $7.78-$ & $9.08-$ & $6.64-$ & $5.96-$ & $13.94-$ & $13.28-$ & \multirow{2}{*}{ Anla } \\
\hline
\end{tabular}

Tablo 7'de ifade edildiği üzere güvenirlik açısından ulaşılan KR20 ve iki yarı test güvenirliği sonuçlarının kabul edilebilir sınırlar içinde olduğu görülmektedir. Madde analizi açısından ise madde güçlüğü ve madde ayırt ediciliği değerlerinin referans değerleri karşıladığı ve alt-üst gruplar arasında uygulanan $t$-Testi sonuçlarının anlamlı olduğu belirlenmiştir. Bu bulgulara göre EGBA kapsamında yer alan testlerin iç tutarlık ve iki yarı test güvenirliği katsayılarına göre test ölçümlerinin güvenilir sonuçlar taşıdığı ifade edilebilir. Ayrıca testlerde yer alan maddelerin ayırt edicilik puanlarının istenen düzeyde olduğu, bireyleri birbirinden ayırt ettiği ve ölçümlerin güvenilir sonuçlar taşıdığı ifade edilebilir. 


\section{Tartışma, Sonuç ve Öneriler}

Erken Okuryazarlık Gelişimini Belirleme Aracı (EGBA) ilkokula başlayan çocukların erken okuryazarlık gelişimlerini belirlemek üzere farklı alt testlerin bir araya getirilmesi ile oluşturulmuştur. Araçta erken okuryazarlık becerilerini değerlendirmek üzere ilgili alan yazın doğrultusunda 1) Temel Görsel Alg1 (TGA), 2) Dinleme, İzleme ve Anlama (DİA), 3) Görsel Okuma ve Anlama (GOA), 4) Sesbilgisel Farkındalık (SF), 5) Yazı Farkındalığı (YF) ve 6) Temel Yazma Becerileri (TYB) testlerine yer verilmiştir.

Türkiye'de ve yurt dişında erken okuryazarlık becerilerini değerlendirmeye yönelik farklı öğretimsel amaçlar taşıyan pek çok araç geliştirildiği görülmektedir (Metropolitan Readiness Tests, Sixth Edition (MRT6); Dynamic Indicators of Basic Early Literacy Skills (DIBELS); Early Literacy Skills Assessment (ELSA); Get Ready to Read; Test of Preschool Early Literacy (TOPEL); Erken Okuryazarlık Becerilerini Değerlendirme Aracı; Erken Okuryazarlık Testi gibi). Türkiye' de ise son yıllarda erken okuryazarlık becerilerini değerlendirmenin genel bir alandan daha özel bir alana doğru ilerlediği görülmektedir. Erken okuryazarlık becerileri, ilköğretime hazırbulunuşluk veya okul olgunluğu gibi geniş bir alanı ifade eden kavramlar içinde ele alınırken son yıllarda yapılan çalışmalarda (Karaman, 2013; Kargın, Ergül, Büyüköztürk ve Güldenoğlu, 2015; Yangın, Yangın ve Erdoğan, 2008; Yazıc1, 2010) erken okuryazarlık becerilerinin sesbilgisel farkındalık, yazı farkındalığı, dinlediğini anlama, kelime tanıma gibi formel okuma ve yazma becerilerinin yordayıcısı olarak düşünülen beceriler olarak daha özel bir alan içerisinde ele alındığı ifade edilebilir. Bu durum Türkiye' de okuryazarlık becerilerinin gelişimine ve formel olarak okuma ve yazma becerisinin kazanılmasına yönelik bir bakış açısı değişikliği sürecinde olunduğunu da göstermektedir. Okuma ve yazmanın öğrenilmesi sürecinde ulaşılması gereken bir olgunluk düzeyi ya da yaş kriterinin günümüz araştırma sonuçları (Neumann, 2016; Neumann, Finger ve Neumann, 2016; Rvachew, Rees, Carolan ve Nadig, 2017 gibi) ile bağdaşmamaktadır. Diğer taraftan doğumdan itibaren yaşanan okuryazarlık deneyimlerinin formel olarak okuma yazma becerisinin öğrenilmesi sürecinde önemli bir etkisinin olduğu da pek çok çalışmanın sonuçları (Barratt-Pugh ve Rohl, 2000; Stickland ve Morrow, 1998; Teale ve Sulzby, 1988; Whitehurst ve Lonigan, 1998) arasında yer almaktadır. Bu nedenle doğumdan itibaren her çocuk okuryazar olma sürecindedir ve formel okuma ve yazma becerilerinin kazanılması sürecinde doğumdan itibaren edinilen okuryazarlık deneyimlerinin önemli bir etkisi bulunmaktadır. Erken Okuryazarlık Gelişimini Belirleme Aracı da ilkokula başlayan çocukların erken okuryazarlık gelişiminin değerlendirmesi ve formel olarak okuma ve yazma becerilerinin kazanılması sürecinde ihtiyaç duyulan desteğin belirlenebilmesi için oluşturulmuş bir araçtır. Karaman (2013) okul öncesi eğitim sürecindeki çocukların erken okuryazarlık becerilerini sesbilgisel farkındalık, yazı farkındalığı, öyküyü anlama, görselleri eşleştirme ve yazı yazma öncesi beceriler boyutları altında değerlendirmiştir. Kargın, Ergül, Büyüköztürk ve Güldenoğlu (2015) okul öncesi eğitim sürecindeki çocukların erken okuryazarlık becerilerinin gelişimini alıcı dilde sözcük bilgisi, ifade edici dilde sözcük bilgisi, genel isimlendirme, işlev bilgisi, harf bilgisi, sesbilgisel farkındalık ve dinlediğini anlama boyutları altında değerlendirmiştir. Good ve Kaminski (2002) okul öncesi eğitim sürecinde ve birinci sınıfta bulunan çocukların okuryazarlık gelişimlerini okuma yazma becerilerinin 
yordayıcısı olarak belirlediği harf isimlendirme akıcılığı, ilk ses akıcılığı, sesbirim bölme akıcılığı, anlamsız kelime okuma akıcılığı boyutları altında değerlendirmiştir. Lombardino, Liberman ve Brown (2005) okul öncesi eğitim ile ilkokul üçüncü sınıf aralığında bulunan çocukların okuryazarlık ve dil gelişimlerini dil, fonolojik farkındalık, alfabe bilgisi, yazı farkındalığı, akıcılık ve anlama boyutları altında değerlendirmiştir. Lonigan, Wagner, Torgesen ve Rashotte (2007) erken okuryazarlık becerilerinin gelişimini yazı bilgisi, kelime tanıma ve sesbilgisel farkındalık boyutları altında değerlendirmiştir. Pek çok farklı araştırmacı (Büyüktaşkapu, 2012; Farver, Nakamoto ve Lonigan, 2007; Lonigan, Allan ve Lerner, 2011; Oktay, 2010; Şimşek, 2011; Yazıc1, 2010 gibi) tarafından da benzer yapılar üzerinde durularak erken okuryazarlık becerilerinin gelişimini değerlendirmeye yönelik araçların oluşturulduğu görülmektedir. Erken Okuryazarlık Gelişimini Belirleme Aracı da bu çalışmalara ek olarak okul öncesi eğitim alan ve almayan 60 - 84 ay aralığındaki çocukların erken okuryazarlık becerilerinin gelişimini temel görsel alg1, dinleme/izleme ve anlama, görsel okuma ve anlama, sesbilgisel farkındalık, yazı farkındalığı ve temel yazma becerileri boyutları altında değerlendirmektedir. Analiz sonuçları araçta yer alan testlerin ölçümlerinin geçerli ve güvenilir sonuçlar taşıdığını göstermektedir. Bu sonuçlar doğrultusunda,

- Öğretmenler ve uzmanlar 60 - 84 ay yaş aralığında bulunan çocukların okuryazarlık gelişimini ya da okuma yazmaya hazırbulunuşluk durumunu incelemek ve değerlendirmek için EGBA'yı kullanabilirler.

- Araştırma sonuçlarına göre erken okuryazarlık becerileri açısından, çocuklar ilkokula geldiklerinde farklı gelişim özellikleri göstermektedir. Öğrencilerin gelişimini gözlemlemek için EGBA kapsamında geliştirilen Temel Görsel Alg1, Dinleme, İzleme ve Anlama, Görsel Okuma ve Anlama, Sesbilgisel Farkındalık; Yazı Farkındalığı ve Temel Yazma Becerileri Testlerini ayrı ayrı kullanabilirler.

- EGBA kapsaminda erken okuryazarlık becerileri olarak görsel ve işitsel alg1, dinlediğini anlama, görsel okuma, yazma çalışmaları, yazı farkındalığı, sesbilgisel farkındalık, kelime bilgisi ve alfabe bilgisi becerileri üzerinde durulmuştur. Araştırmacılar yaş ve grup özelliklerini de dikkate alarak farklı becerileri bir araya getirerek yeni araç geliştirme çalışmaları yapabilirler.

\section{Kaynakça}

Akyol, H. (2007). Türkçe ilk okuma yazma öğretimi. (Yeni Programa Uygun 6. Bask1). Ankara: Pegem.

Alisinanoğlu, F., ve Şimşek, Ö. (2012). Okuma yazmaya hazırlık çalışmalarının okul öncesi dönemdeki çocukların yazmaya hazırlık becerilerine etkisinin incelenmesi. Pegem Ĕ̆itim ve Öğretim Dergisi, 2(2), 1-14. https:/ / doi.org/10.14527/C2S2M1

Aram D., and Biron, S. (2004) Joint storybook reading and joint writing interventions among low SES preschoolers: differential contributions to early literacy. Early Childhood Research Quarterly, 19, 588-610.

https:/ / doi.org/10.1016/j.ecresq.2004.10.003 
Arıkök, İ. (2001). Beş - altı yaş çocuklarında görsel algı eğitiminin okuma olgunluğuna olan etkisinin incelenmesi. (Yayınlanmamış Yüksek Lisans Tezi). Gazi Üniversitesi, Ankara.

Armbruster, B. B., Lehr, F., and Osborn, J. (2006). Çocuk bir okur oluyor ebeveynler için kanıtlanmış araştırma sonuçları, doğum-okul öncesi dönemi. National Institute for Literacy. http://www.ilipg.org/sites/ilipg.org/files/documents/2011/02/childbecomes-readertr.pdf adresinden erişildi.

Ateş, S. (2011). İlköğretim beşinci sinıf Türkçe dersi öğrenme-öğretme sürecinin anlama öğretimi açısından değerlendirilmesi. (Yayınlanmamış Doktora Tezi). Gazi Üniversitesi, Ankara.

Badian, A. N. (2001). Phonological and orthographic processing: Their roles in reading prediction. Annals of Dyslexia. 51(1), 177 - 202. https:/ / doi.org/10.1007/ s11881001-0010-5

Barratt-Pugh, C., and Rohl, M. (2000). Literacy learning in the early years crows nest. Sidney: Allen and Unwin.

Baykul, Y. (2010). Eğitimde ve psikolojide ölçme: Klasik test teorisi ve uygulaması. Ankara: Pegem.

Bayraktar, V. ve Temel, F. (2014). Okuma-yazmaya hazırlık eğitim programının çocukların okuma yazma becerilerine etkisi. Hacettepe Üniversitesi Eğitim Fakültesi Dergisi 29(3), 8 - 22.

Bentin, S., and Leshem, H. (1993). On the interaction between phonological awareness and reading acquisition: It'sa two-way street. Annals of dyslexia, 43(1), 125. https:/ / doi.org/10.1007/BF02928178

Block, C. C. (2003). Literacy difficulties: diagnosis and instruction for reading specialists and classroom teachers. New York: Pearson.

Bradley, L., and Bryant, P. (1983). Categorizing sounds and learning to read: A causal connection. Nature, 301, 419-421. https:/ / doi.org/10.1038/301419a0

Büyüköztürk, Ş., Çakmak, E., Akgün, Ö., Karadeniz, Ş. ve Demirel, F. (2011). Bilimsel araştırma yöntemleri (10. Bask1). Ankara: Pegem.

Büyüktaşkapu, S. (2012). Mountain shadows fonolojik farkındalık ölçeğinin (ms-pas) Türkçe' ye uyarlanması geçerlik güvenirlik çalışması, International Online Journal of Educational Sciences, 4(2), 509-518.

Delican, B. (2013). Uyum ve hazırlık çalışmaları programının ilk okuma yazmaya hazıroluşluğa etkisi ve uygulamaya ilişkin öğretmen görüşleri. (Yayınlanmamış Yüksek Lisans Tezi). Gazi Üniversitesi, Ankara.

Durkin, D. (1968). When should children begin to read. Innovation and change in reading instruction, The 67th yearbook of the National Society of Education, 30-71.

Erdoğan, Ö. (2009). İlköğretim birinci sınıf ögrrencilerinin fonolojik farkındalık becerileri ile okuma ve yazma becerileri arasındaki ilişki. (Yayınlanmamış Yüksek Lisans Tezi). Hacettepe Üniversitesi, Ankara.

Erduran, E. (1999). Okul öncesi eğitimde okuma yazmaya hazırlık programları ve bilişsel yetenek özelliklerinin okuma sürecine etkileri. (Yayınlanmamış Yüksek Lisans Tezi). Marmara Üniversitesi, İstanbul.

Erkan, S. (2011). Farklı sosyo-ekonomik düzeydeki ilköğretim öğrencilerinin okula hazırbulunuşluklarının incelenmesi. Hacettepe Üniversitesi Eğitim Fakültesi Dergisi. 40, $186-197$. 
Ezell, H. K., Justice, L. M., and Parsons, D. (2000). Enhancing the emergent literacy skills of preschoolers with communication disorders: A pilot investigation. Child Language Teaching and Therapy, 16, 121-140. https:/ / doi.org/10.1191/026565900675456266

Farver J. M., Nakamoto J., and Lonigan C. J. (2007) Assessing preschoolers' emergent literacy skills in English and Spanish with the Get Ready to Read! Screening Tool. Annals of Dyslexia, 57, 161-178. https:/ / doi.org/10.1007/s11881-007-0007-9

Field, A. (2009). Discovering statistics using SPSS. California: Sage.

Gökkuş, İ. (2016). Erken okuryazarlık becerilerinin gelişiminde ses bilgisi farkındalık programının etkisi. (Yayınlanmamış Doktora Tezi). Gazi Üniversitesi, Ankara.

Harrington, D. (2009). Confirmatory factor analysis. Oxford University Press. https:/ / doi.org/10.1093/acprof:oso/9780195339888.001.0001

Hutcheson, G. D., and Sofroniou, N. (1999). The multivariate social scientist: Introductory statistics using generalized linear models. California: Sage. https:/ / doi.org/10.4135/9780857028075

Invernizzi, M., Justice, L., Landrum, T. J., and Booker, K. (2004). Early literacy screening in kindergarten: Widespread implementation in Virginia. Journal of Literacy Research, 36(4), 479-500. https://doi.org/10.1207/s15548430jlr3604_3

Justice, L. M., and Ezell, H. K. (2000). Enhancing children's print and word awareness through home-based parent intervention. American Journal of Speech-Language Pathology, 9, 257-269. https:/ / doi.org/10.1044/1058-0360.0903.257

Justice, L., Invernizzi, M., and Meier, J. (2002). Designing and implementing an early literacy screening protocol: Suggestions for the speech-language pathologist. Language, Speech, and Hearing Services in Schools, 33, 84-101. https:/ / doi.org/10.1044/0161-1461(2002/007)

Karaman, G. (2013). Erken okuryazarlık becerilerini değerlendirme aracı'nın geliştirilmesi, geçerlik ve güvenirlik çalışması. (Yayınlanmamış Doktora Tezi). Gazi Üniversitesi, Ankara.

Karasar, N. (2009). Bilimsel araştırma yöntemi. Ankara: Nobel.

Kargın, T., Ergül, C., Büyüköztürk, Ş. ve Güldenoğlu, B. (2015). 60-72 aylık çocuklara yönelik Erken Okuryazarlık Testi (EROT) geliştirme çalışması. Ankara Üniversitesi Ĕ̆itim Bilimleri Fakültesi Özel Eğitim Dergisi, 16(3), 237-270.

Kim, D., Kim, W., and Lee, K. (2007). The relationship between phonological awareness and early reading for first grade Korean language learners with reading difficulties. Asia Pacific Education Review, 8(3), 426-434. https:/ / doi.org/10.1007/BF03026471

Lombardino, L. J., Lieberman, R. J., and Brown, J. C. (2005). assessment of literacy and language (all).

http://www.pearsonclinical.com/language/products/100000404/ assessmentof-literacy-and-language-all-all.html. adresinden erişildi.

Lonigan, C. J. (2006). Development, assessment, and promotion of preliteracy skills. Early Education and Development, 17 (1), 91-114. https:/ / doi.org/10.1207/s15566935eed1701_5

Lonigan, C. J., Wagner, R. K., Torgesen, J. K., and Rashotte, C. A. (2007). Topel: Test of preschool early literacy. Texas: Pro-Ed. 
Lonigan, C. J., Allan, N. P., and Lerner, M. D. (2011). Assessment of preschool early literacy skills: Linking children's educational needs with empirically supported instructional activities. Psychology in the Schools, 48(5), 488 - 501. https:/ / doi.org/10.1002/pits.20569

MEB, (2005). ilköğretim Türkçe dersi öğretim programı ve kılavuzu. Ankara: MEB.

MEB, (2015). Millî eğitim istatistikleri örgün eğitim 2013-2014. Ankara: MEB.

https://sgb.meb.gov.tr/istatistik/meb_istatistikleri_orgun_egitim_2013_2014.pd $\mathrm{f}$ adresinden erişildi.

Morrow, L. M. (2007). Developing literacy in preschool. New York: The Guilford.

Neumann, M. M., and Neumann, D. L. (2014). Touch screen tablets and emergent literacy. Early Childhood Education Journal, 42(4), 231-239. https:/ / doi.org/10.1007/s10643-013-0608-3

Neumann, M. M., Hood, M., and Neumann, L. N. (2009). The scaffolding of emergent literacy skills in the home environment: A case study. http://www98.griffith.edu.au/dspace/bitstream/handle/10072/29592/59672_1 .pdf?sequence $=1$ adresinden erişildi.

Oktay, A. (2010). İlköğretime hazır oluş ve hazır oluşu etkileyen temel faktörler. Oktay, A. (Ed). Illköğretime hazırlık ve ilköğretim programları. (21-34). Ankara: Pegem.

Öztunç, S. (1994). Okuma kavramları testinin Türk çocuklarına uyarlanması.

(Yayınlanmamış Yüksek Lisans Tezi). Marmara Üniversitesi, İstanbul.

Polat Unutkan, Ö. P. (2003). Marmara ilköğretime hazır oluş ölçeğinin geliştirilmesi ve standardizasyonu. (Yayınlanmamış Doktora Tezi). Marmara Üniversitesi, İstanbul.

Riley, J. (2006) Learning in the years a guide for teachers of children 3-7. Wiltshire: Cromwell Rohde, L. (2015). The comprehensive emergent literacy model: Early literacy in context. SAGE Open, 5(1). https:/ / doi.org/10.1177/2158244015577664

Sonnenschein, S., and Munsterman, K. (2002). The influence of home-based reading interactions on 5-year-olds' reading motivations and early literacy development. Early Childhood Research Quarterly. 17, 318-337. https://doi.org/10.1016/S08852006(02)00167-9

Strickland, D. S. (1998). Teaching Phonics Today: A Primer for Educators. Order Department, International Reading Association. https:/ / files.eric.ed.gov/fulltext/ED470299.pdf adresinden erişildi.

Şimşek, Ö. (2007). Anasınıfina devam eden çocukların okuma olgunluğu düzeyine Türkçe dil etkinlik programının etkisinin incelenmesi. (Yayınlanmamış Yüksek Lisans Tezi). Gazi Üniversitesi, Ankara.

Şimşek, Ö. (2011). 60- 72 aylık çocukların yazı farkındalığı ve yazmaya hazırlık becerilerinin gelişiminde okuma yazmaya hazırlı programını etkisinin incelenmesi.

(Yayınlanmamış Yüksek Lisans Tezi). Gazi Üniversitesi, Ankara.

Tabachnick, B. G., and Fidell, L. S. (2007). Using multivariate statistics. New York: Pearson

Tavşancıl, E. (2002). Tutumların ölçülmesi ve SPSS ile veri analizi. Ankara: Nobel.

Teale, W. H., and Sulzby, E. (1986). Emergent literacy as a perspective for examining how young children become writers and readers. Emergent literacy: Writing and reading, $7-25$.

Teale, W. H., Hiebert, E. H., and Chittenden, E. A. (1987). Assessing young children's literacy development. The Reading Teacher, 40(8), 772-777. 
Turan, F. ve Akoğlu, G. (2011). Okul öncesi dönemde sesbilgisel farkındalık eğitimi. Ĕ̈itim ve Bilim, 36(161), 64 -75.

Turgut, M. F. ve Baykul, Y. (2010). Ĕ̆itimde ölçme ve değerlendirme. Ankara: Pegem

Uyanık, Ö. (2010). Ankara örnekleminde kaufman erken akademik ve dil becerileri araştırma testi'nin 61-72 aylık Türk çocuklarına uyarlanması. (Yayınlanmamış Yüksek Lisans Tezi). Gazi Üniversitesi, Ankara.

Van Kleeck, A., and Schuele, C. M. (2010). Historical perspectives on literacy in early childhood. American Journal of Speech-Language Pathology, 19(4), 341-355. https:/ / doi.org/10.1044/1058-0360(2010/09-0038)

Van Vechten, D. (2013). Impact of home literacy environments on students from low socioeconomic status backgrounds. (Master's thesis).

2016.http:/ / fisherpub.sjfc.edu/cgi/viewcontent.cgi?article=1249\&context=educa tion_ET adresinden erişildi.

Vellutino, F. R., and Scanlon, D. M. (1987). Phonological coding, phonological awareness, and reading ability: Evidence from a longitudinal and experimental study. Merrill-Palmer Quarterly (19), 321-363.

Wagner, R., Torgesen, J., Rashotte, C., and Pearson, N. A. (2013). Comprehensive test of phonological processing - Second edition.

http:/ / www.proedinc.com/customer/productview.aspx?id=5187 adresinden erişildi.

Whitehurst, G., and Lonigan, C. (1998). Child development and emergent literacy. Child Development, 69(3), 848-872. https:/ / doi.org/10.1111/j.1467-8624.1998.tb06247.x

Wilson S. B., and Lonigan C. J. (2009). Emergent literacy screeners for preschool children: an evaluation of get ready to read! and individual growth and development indicators. Annals of Dyslexia, 59, 115-131.

https:/ / doi.org/10.1007/s11881-009-0026-9

Yangın, B. (2007). Okul öncesi eğitim kurumlarındaki altı yaş çocuklarının yazmayı öğrenmeye hazırbulunuşluk durumları. Hacettepe Üniversitesi Ĕ̆itim Fakültesi Dergisi, 32, 294 - 305.

Yazıc1, E. (2010). 61 -72 aylık çocuklar için okuma yazma becerileri araştırma testinin geçerlik ve güvenirlik çalışması. (Yayınlanmamış Yüksek Lisans Tezi). Gazi Üniversitesi, Ankara.

\section{Summary}

\section{Introduction}

Researchers are developing many programs to support early literacy skills. In addition, researchers evaluate the development of literacy with various measurement tools (Badian 2001; Bayraktar and Temel, 2014; Justice and Ezell, 2000; Whitehurst and Lonigan, 1998; Sonnenschein ve Munsterman, 2002; Şimşek, 2007). In Turkey, the developed or adapted assessment tools for early literacy skills can be said to be limited. According to researchers, factors such as phonological awareness, print awareness, small muscle skills, visual perception, auditory perception, attention and memory are important in learning to literacy. (Akyol, 2007; Lieberman and Brown, 2005; Lonigan, Burgess and Anthony, 2000; Mayer, 2007; Neumann, Hood and Neumann, 2009). Therefore, the main purpose of this study was to develop a measurement tool to 
evaluate the literacy development of the first grade students. For this purpose, Early Literacy Diagnostic Assessment Tool (ELDAT) was developed and the validity and reliability studies of the tool were conducted.

\section{Method}

The research was planned as a survey model involving scale development. In line with the scale development process, subscales were determined based on literature and other studies, and expert opinions were asked. Subscales were revised based on expert opinions, and item pool was generated. In this process, definitions and indicators were determined for each subscale, and items were generated to encounter each indicator. The research sample included 781 first grade students who were 60-84 months old. Then, the item pool was presented to expert opinion, and some revisions were made. Thus, Early Literacy Diagnostic Assessment Tool (ELDAT) was created in line with the relevant literature, sample studies and expert opinions. According to the results and expert opinions, Early Literacy Diagnostic Assessment Tool (ELDAT) involved 269 items. In the main study, the Early Literacy Diagnostic Assessment Tool (ELDAT) was administered to 800 students in the sample by 15 practitioners and two researchers. The validity, reliability and item analysis studies were performed on the data obtained from 781 students.

\section{Results}

The results of statistical analysis were as follows; BVP Test was valid and reliable with 17 items collected under 4 dimensions. LMC Test was valid and reliable with 20 items collected under 1 dimension. VRC Test was valid and reliable with 15 items collected under 3 dimensions. PA Test was valid and reliable with 55 items collected under 8 dimensions. Print Awareness (PRA) Test was valid and reliable with 15 items collected under 2 dimensions. Basic Writing Skills Test was valid and reliable with 16 items collected under 2 dimensions.

\section{Discussion}

Many researchers have developed tools to assess the development of early literacy Skills (Metropolitan Readiness Tests, Sixth Edition (MRT6); Dynamic Indicators of Basic Early Literacy Skills (DIBELS); Early Literacy Skills Assessment (ELSA); Get Ready to Read; Test of Preschool Early Literacy). In addition to these studies, the Early Literacy Diagnostic Assessment Tool also evaluates under the dimensions of basic visual perception, listening / watching and understanding, visual reading and understanding, phonological awareness, writing awareness and basic writing skills. The results indicated that the measurement tools have valid and reliable results. It is seen that the scores obtained from the Early Literacy Diagnostic Assessment Tool differ significantly in terms of variables. These results support the fact that the Early Literacy Diagnostic Assessment Tool is successful in distinguishing individuals.

\section{Pedagogical Implications}

Research results show that children are at a different level in terms of literacy development. Parents can learn about the development of their child's literacy skills by implementing tools developed to evaluate their early literacy skills. 


\section{Araştırmanın Etik Taahhüt Metni}

Yapılan bu çalışmada bilimsel, etik ve alıntı kurallarına uyulduğu; toplanan veriler üzerinde herhangi bir tahrifatın yapılmadığı, karşılaşılacak tüm etik ihlallerde "Cumhuriyet Uluslararası Eğitim Dergisi ve Editörünün" hiçbir sorumluluğunun olmadığ1, tüm sorumluluğun Sorumlu Yazara ait olduğu ve bu çalışmanın herhangi başka bir akademik yayın ortamına değerlendirme için gönderilmemiş olduğu sorumlu yazar tarafından taahhüt edilmiştir.

\section{Authors' Biodata/ Yazar Bilgileri}

Burak DELİCAN Tokat Gaziosmanpaşa Üniversitesi, Eğitim Fakültesi, Temel Eğitim Bölümünde öğretim üyesi olarak görev yapmaktadır. Çalışma alanları Okuryazarlık Gelişimi, İlk Okuma Yazma Öğretimi ve Türkçe Eğitimidir.

Burak Delican works as an assistant professor in Faculty of Education, Tokat Gaziosmanpaşa University, Tokat, Turkey. His research interests include literacy development, reading and writing, and Turkish education

Seyit ATEŞ Gazi Üniversitesi, Gazi Eğitim Fakültesi, Temel Eğitim Bölümünde öğretim üyesi olarak görev yapmaktadır. Çalışma alanları Çocuk Edebiyatı, İlk Okuma Yazma Öğretimi ve Türkçe Eğitimidir.

Seyit Ateş works as a professor in Gazi Faculty of Education, Gazi University, Ankara, Turkey. His research interests include child literature, reading and writing, and Turkish education. 